\title{
IVE Regimen
}

National Cancer Institute

\section{Source}

National Cancer Institute. IVE Regimen. NCI Thesaurus. Code C140105.

A regimen consisting of ifosfamide, epirubicin and etoposide that can be used in the treatment of non-Hodgkin lymphoma (NHL), Hodgkin lymphoma $(\mathrm{HL})$, and as a stem cell mobilization regimen. 